\title{
CROSS-CULTURAL ADAPTATION OF THE POSITIVE MENTAL HEALTH QUESTIONNAIRE FOR NURSING STUDENTS IN THE BRAZILIAN CONTEXT
}

Kayo Henrique Jardel Feitosa Sousa' ${ }^{1}$ (D) Maria Teresa Lluch-Canut ${ }^{2}$ (D) Cristiane Helena Gallasch ${ }^{3}$ (D) Regina Célia Gollner Zeitoune ${ }^{1}$ (1)

${ }^{1}$ Universidade Federal do Rio de Janeiro, Escola de Enfermagem Anna Nery, Programa de Pós-Graduação em Enfermagem. Rio de Janeiro, Rio de Janeiro, Brasil. ${ }^{2}$ Universidade de Barcelona, Faculdade de Medicina e Ciências da Saúde, Escola de Enfermagem. Barcelona, Espanha. ${ }^{3}$ Universidade do Estado do Rio de Janeiro, Faculdade de Enfermagem, Programa de Pós-Graduação em Enfermagem. Rio de Janeiro, Rio de Janeiro, Brasil.

\begin{abstract}
Objective: to describe the cross-cultural adaptation process of the Positive Mental Health Questionnaire for undergraduate Nursing students, in the Brazilian context.

Method: a psychometric study conducted in public universities in Rio de Janeiro/Brazil, between October 2019 and July 2020. The transcultural adaptation process encompassed the following stages: translation; reconciliation; back-translation; independent reviews by a committee of reviewers; pre-completion; completion; harmonization; formatting and review; cognitive test with 31 undergraduate Nursing students from two public universities; and analysis of the comments.

Results: the process lasted approximately ten months, and the initial translations, carried out independently by two translators, achieved close versions; none of the translators reported difficulties in translating the meanings of the items. The Brazilian version of the instrument maintained conceptual, semantic, idiomatic, and experimental equivalences. The mean content validity ratio values for clarity, relevance, pertinence, and theoretical dimension were higher than established; the assessment by the target audience showed good understanding.

Conclusion: the Positive Mental Health Questionnaire - Brazilian version showed equivalence with the original version, developed in Spain, and presented satisfactory evidence of content validity for use with undergraduate Nursing students in Brazil, being easy-to-understand by the target audience.
\end{abstract}

DESCRIPTORS: Nursing. Mental health. Nursing students. Translation. Validation studies. Cross-cultural comparison. Psychometrics. Positive Psychology. 


\section{ADAPTAÇÃO TRANSCULTURAL DO CUESTIONARIO DE SALUD MENTAL POSITIVA PARA ESTUDANTES DE ENFERMAGEM NO CONTEXTO BRASILEIRO}

\section{RESUMO}

Objetivo: descrever o processo de adaptação transcultural do Cuestionario de Salud Mental Positiva, para estudantes de graduação em enfermagem, no contexto brasileiro.

Método: estudo psicométrico realizado em universidades públicas no Rio de Janeiro/Brasil, entre outubro de 2019 e julho de 2020. O processo de adaptação transcultural compreendeu as etapas: tradução; reconciliação; retrotradução; revisões independentes por comitê de revisores; pré-finalização; finalização; harmonização; formatação e revisão; teste cognitivo com 31 estudantes de graduação em enfermagem de duas universidades públicas; e análise dos comentários.

Resultados: o processo durou aproximadamente dez meses, e as traduções iniciais, realizadas por dois tradutores de forma independente, chegaram a versões próximas; nenhum dos tradutores referiu dificuldade na tradução de significados dos itens. A versão brasileira do instrumento manteve equivalências conceitual, semântica, idiomática e experimental. Os valores médios do content validity ratio para clareza, relevância, pertinência e dimensão teórica foram superiores ao estabelecido; a avaliação pelo público-alvo demonstrou boa compreensão.

Conclusão: o Questionário de Saúde Mental Positiva - versão brasileira demonstrou equivalência com a versão original, desenvolvida na Espanha, e apresentou evidências de validade de conteúdo satisfatórias para uso com estudantes de graduação em enfermagem, no Brasil, sendo de fácil compreensão ao públicoalvo.

DESCRITORES: Enfermagem. Saúde mental. Estudantes de enfermagem. Tradução. Estudos de validação. Comparação transcultural. Psicometria. Psicologia positiva.

\section{ADAPTACIÓN TRANSCULTURAL DEL CUESTIONARIO DE SALUD MENTAL POSITIVA PARA ESTUDIANTES DE ENFERMERÍA EN EL CONTEXTO BRASILEÑO}

\section{RESUMEN}

Objetivo: describir el proceso de adaptación transcultural del Cuestionario de Salud Mental Positiva para estudiantes de grado de enfermería en el contexto brasileño.

Método: estudio psicométrico realizado en universidades públicas de Río de Janeiro/Brasil, entre octubre de 2019 y julio de 2020. El proceso de adaptación transcultural se llevó a cabo por etapas: traducción; reconciliación; retrotraducción; revisiones independientes por comité de revisores; prefinalización; finalización; armonización; formateo y revisión; prueba cognitiva con 31 estudiantes de grado de enfermería de dos universidades públicas y análisis de los comentarios.

Resultados: el proceso duró aproximadamente diez meses y las traducciones iniciales, realizadas por dos traductores de manera independiente, llegaron a versiones aproximadas; ningún traductor relató dificultades en la traducción de los significados de los ítems. La versión brasileña del instrumento mantuvo equivalencia conceptual, semántica, idiomática y experimental. Los valores promedios del content validity ratio para claridad, relevancia, pertinencia y dimensión teórica fueron superiores a lo establecido; la evaluación por el público objetivo demostró una buena comprensión.

Conclusión: el Cuestionario de Salud Mental Positiva, versión brasileña mostró equivalencia con la versión original, desarrollada en España, y presentó evidencias de validez de contenido satisfactorias para su uso con estudiantes de grado de enfermería en Brasil, por ser de fácil comprensión para el público objetivo.

DESCRIPTORES: Enfermería. Salud mental. Estudiantes de enfermería. Traducción. Estudios de validación. Comparación transcultural. Psicometría. Psicología positiva. 


\section{INTRODUCTION}

Various definitions are used for the term "mental health"1. The World Health Organization (WHO) proposes the following definition for mental health: "a state of well-being in which the individual realizes his or her own abilities, can cope with the normal stresses of life, can work productively and fruitfully, and is able to make a contribution to his or her community"1:12. It is therefore clear that this definition is close to a positive aspect of the concept of health.

In an informative document on the promotion of mental health, the WHO mentioned various perspectives for understanding what is called Positive Mental Health (PMH), among which is the cultural approach advocated by Marie Jahoda, in 1958 ${ }^{1}$. In this approach, $\mathrm{PMH}$ involves the capacity for self-fulfillment, mastery over the environment, and a sense of autonomy. From a theoretical essay, a model was developed that contemplated six essential factors for $\mathrm{PMH}$, regardless of being affected by some mental disease, namely: attitudes towards oneself; growth and self-updating; integration; autonomy; mastery of the environment; and perception of reality. For each factor, multiple criteria had to be attained ${ }^{2}$.

Subsequently, the concept of PMH was developed towards a multifactorial construction and came to be understood as a dynamic state of optimal affective, relational, and cognitive functioning. Such a state depends on the ability of the person or group to relate to themselves, to each other and to the environment. The purpose of this relationship is to develop their potential and the achievement of individual and collective goals, maintaining the balance between expectations and the reality experienced ${ }^{3}$.

This conception was operationalized by Lluch-Canut, in a Positive Mental Health Multifactorial Model which supported the elaboration of the first instrument thoughtfully recommended to measure $\mathrm{PMH}$ - the Positive Mental Health Questionnaire (Cuestionario de Salud Mental Positiva, CSM+) with undergraduate Nursing students as target audience ${ }^{4}$. This instrument consists of 39 items scored on a of self-completion Likert scale. The minimum and maximum values for the global scale are 39 and 156, respectively. The higher the $\mathrm{PMH}$, the higher the score ${ }^{4}$.

The 39 items of the scale are divided into six factors: (1) personal satisfaction in different life spheres, sense of self-esteem and optimism (items 4,6,7,12,14,31, 38 and 39); (2) pro-social attitude associated with the person's sensitivity to their social environment, attitudes of support and help to others and acceptance of different social groups (items 1,3,23, 25 and 37); (3) self-control related to emotional balance, as a requirement for the individual's adaptation, coping with stress, frustrations and anxieties (items 2,5,21, 22 and 26); (4) autonomy referred to as the person's ability to make decisions based on their own criteria, self-regulate their conduct and maintain a good level of personal safety (items 10,13,19, 33 and 34); (5) problem-solving and self-updating related to the adoption of an active behavior to face problems, providing flexible attitudes and personal growth (items 15,16,17,27,28,29,32, 35 and 36); and (6) interpersonal skills associated with the ability to communicate with others and develop harmonious interpersonal relationships, in addition to knowing how to listen to others, communicating their feelings and receiving affection, when necessary (items $8,9,11,18,20,24$ and 30$)^{4}$.

By means of a scoping review carried out in the LILACS, CINAHL and SCOPUS databases in April 2020, of a total of 286 articles and after applying the eligibility criteria, 53 studies were identified that assessed the mental health of the undergraduate Nursing students, from a positive perspective. The studies were published between 2010 and April 2020, in Portuguese, English and Spanish. Of these, four used the instrument: one in $\mathrm{Brazil}^{5}$, two in Spain $^{3,6}$ and one multicenter study ${ }^{7}$, involving Portugal and Spain. It is noteworthy, however, that the study ${ }^{5}$ carried out with Brazilian students used the adapted version for the Portuguese population ${ }^{8-9}$, endorsing the conduction of this study, since cultural issues must be considered in the elaboration and cross-cultural adaptation (CCA) of measurement instruments. 
It was identified in the literature that the CSM+ underwent a CCA process for the Portuguese population $^{8-9}$. Its psychometric properties were assessed for Catalan and Portuguese ${ }^{8}$ Nursing students ${ }^{3}$, and Catalan professors ${ }^{10}$. In addition, it was used for measurements among university students ${ }^{5,7,11}$, professors ${ }^{12}$, health professionals ${ }^{13}$ and people with chronic diseases ${ }^{14}$. The diversity of studies shows the interest and importance of the assessment of $\mathrm{PMH}$. It was observed that the CSM+ has been used for the assessment of $\mathrm{PMH}$, aiming to provide and optimize strategies to promote mental health, and as subsidies for the psychosocial intervention programs, showing favorable results ${ }^{8}$.

Provenly, mental health problems constitute a serious public health issue, and university students represent a considerable percentage of people with common mental disorders ${ }^{15}$. For instance, undergraduate Nursing students have shown worse mental health than the others and severe mental disorders ${ }^{16-17}$. It was also verified that admission to the university can trigger stress ${ }^{18}$, including attempted or consummated suicide ${ }^{19}$.

Thus, the assessment of PMH by means of specific instruments that can favor the development of programs to promote mental health is considered important. That is, to act at an early stage in facing adverse events and maintaining mental health, reiterating the importance of this research. Thus, the objective of this study was to describe the CCA process of the CSM+ for undergraduate Nursing students in the Brazilian context.

\section{METHOD}

A psychometric study for the CCA of the CSM+, carried out in two public universities in the city of Rio de Janeiro-RJ, Brazil, between October 2019 and July 2020. For this, the guidelines of the Patient-Reported Outcomes Measurement Information System (PROMIS ${ }^{\circledR}$ ): standards document were followed ${ }^{20}$. Figure 1 presents the flowchart of the stages conducted.

Authorization to adapt the instrument was granted by the author. Two translations (Stage 1) were carried out, independently, by Brazilian natives - fluent in Spanish - one being a layman (Translator 1 - T1) and the other with knowledge in the health area (Translator 2 - T2). A third independent translator also participated, who reconciled the translations (Stage 2), indicating which is the most appropriate or suggesting a new translation, in case of disagreement, pointing out the reasons for accepting the reconciled version as the best option. The reconciled version $(R)$ was subjected to a back-translation process by a native Spanish translator, who had mastery of the Portuguese language spoken in Brazil, independently and without contact with the original version of the instrument (Stage 3).

After the back-translation, the researchers responsible for this study compared the original version, the translations, and the back-translation, to obtain a previous harmonization, avoiding meaning discrepancies between the languages. All the translations and the back-translation were sent to the author of the instrument for her to assess the quality of the process (Stage 4). Thus, the first synthesis version (S1) was obtained.

Stage five - independent reviews - aimed at obtaining the most appropriate translation for each item of the instrument. Two Reviewers Committees were assembled: one for assessing intercultural equivalence and the other for assessing content. The reviewers of both groups were identified through access to the Research Groups Directory of the National Council for Scientific and Technological Development (CNPq), using the following search term: mental health. After the identification of the Research Groups, a search was carried out in the Lattes Platform to identify professionals with expertise in the thematic area and/or method. 


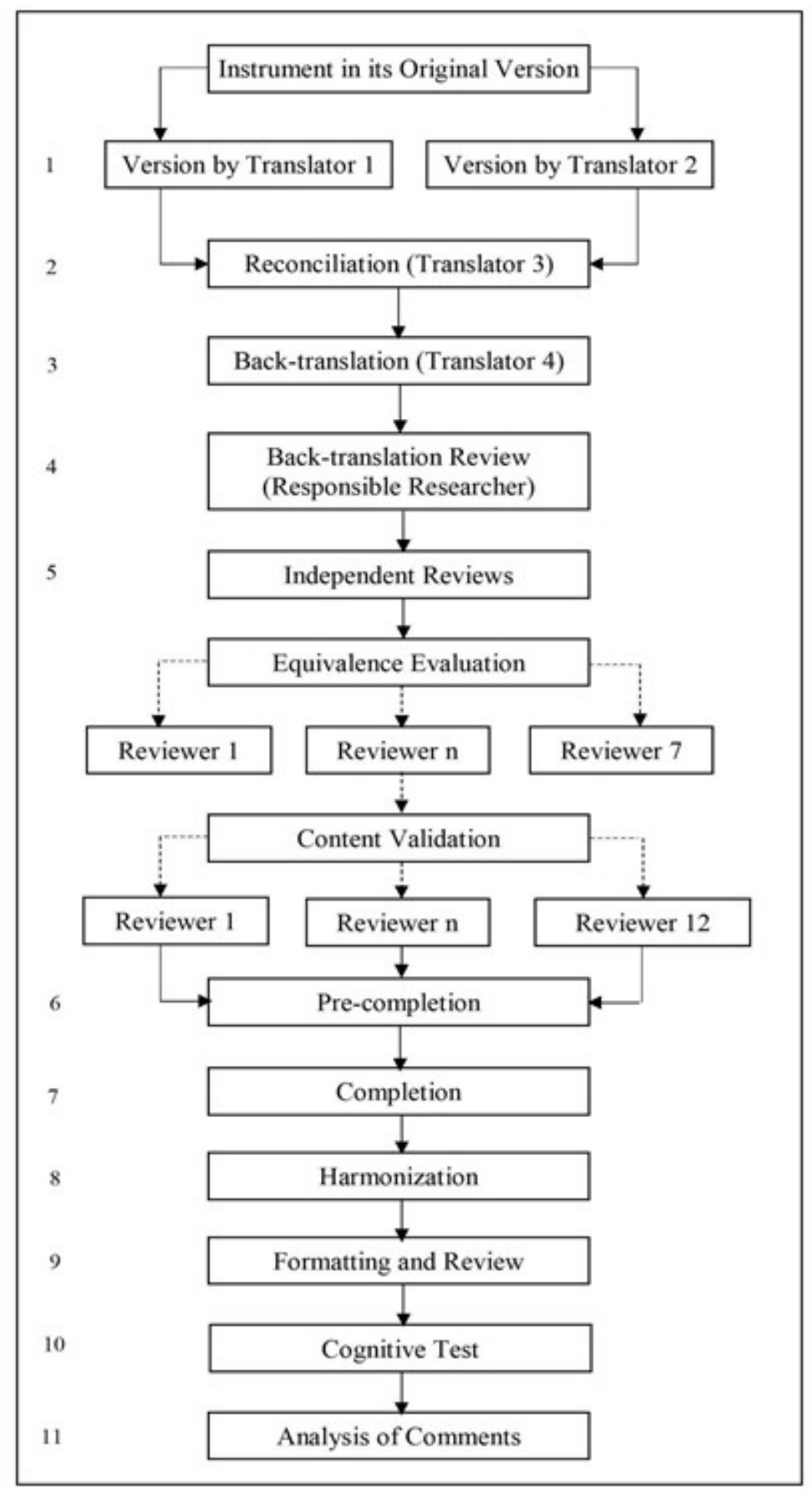

Figure 1 - Flowchart of the methodological stages. Rio de Janeiro, RJ, Brazil, 2019-2020. 
A total of 30 reviewers were invited via email to assemble Reviewers Committee 1, contemplating all geographic regions of the country. Responses were obtained from seven reviewers, without representation of the Midwest region. The composition of the Committee was as follows: five nurse researchers in mental health, who had [self-declared] command of the Spanish language, three with experience in CCA studies or in the development of measurement instruments. Two female Language specialists, Graduates in Letters/Spanish Language, participated as reviewers, being selected for convenience.

This Committee had the objective of assessing the items regarding equivalence: idiomatic (search for equivalent expressions or terms in the target culture), semantic (verifying if the meanings were similar), conceptual (assessment regarding the existence, relevance and acceptability of the concepts) and experimental (determination of whether the situations evoked were adequate to the target cultural context $)^{21}$.

The reviewers were asked to answer the questions to assess agreement regarding the equivalences between the original version and the S1 version, using the yes or no answers. In case of negative answers, the reviewer would decide between the following options: choosing one of the initial translations or suggesting a new translation. For the assessment of the equivalences, the agreement index was used and, as an indicator of suitability, a percentage equal to or greater than $80 \%$ was accepted ${ }^{22}$. As for the items with values lower than the aforementioned, changes were made according to the reviewers' recommendations. It is noteworthy that a female professional with training in Portuguese, qualified to make spelling and grammatical corrections and intentionally selected, participated in the entire process of analyzing the recommendations made by the bilingual reviewers. After the adjustments, the Committee was consulted in relation to the agreement with the referrals made by the researchers, and synthesis version 2 (S2) was obtained.

The new version was sent by email to 42 reviewers to assess elements related to content validity, using the following criteria: clarity (if the items were written in a way that was comprehensible to the target population and appropriate to the concept that was intended to measure);22 pertinence (if the items were representative and measured the construct, faithfully as in the theoretical rationale); ${ }^{22}$ relevance (degree to which each element of the instrument was considered indispensable to achieve the objectives); ${ }^{23}$ and theoretical dimension (if the factors were formed by items that represented a single concept $)^{23}$.

The invitation included researchers with proven experience in the theme and/or method, from all the Brazilian geographic regions. Responses were obtained from 12 researchers, after a 15-day period, again without representation of the Midwest region. The participants were as follows: 11 nurses -4 with experience in CCA studies, psychometry and/or development of measurement instruments; 7 with experience in mental health and 5 in Nursing education, in addition to 1 psychologist with expertise in positive psychology and psychometry. It is noteworthy that the nurses had more than one area of performance, so the sum was greater than 11 .

The reviewers were asked to assess whether the clarity, pertinence and relevance factors were ensured, using the yes or no answers. When they disagreed, comments and suggestions about the item were requested. As for the theoretical dimension, the reviewers were asked to indicate which factor the item belonged to, among the six listed in the theoretical model, with the possibility of checking the option nenhuma das opções anteriores (none of the previous options), when they did not recognize the item as part of the proposed factors. It was considered dimensional when the item was allocated to some factor. 
To assess content validity, the Content Validity Ratio (CVR) was used, which is based on how much the reviewers consider an item to be essential. The reviewers assess the skill or knowledge measured by an item, grouped as essential or not, which in this study correspond to the yes or no marks. The more reviewers assess the item as essential, the greater the degree of content validity ${ }^{24}$.

About the modification of an item, in the study in question, the CVR value for each item was calculated, separately considering the four evidences for content validity and, subsequently, the arithmetic mean of the results was calculated individually. 0.677 was adopted as critical value. The Content Validity Index (CVI) for the entire instrument is the mean CVR for all the items retained ${ }^{24}$.

A second assessment round of the items' content was necessary. The reviewers were consulted if, after the adjustments were made, the items-maintained clarity, pertinence, and relevance. After a 10-day period, the assessments were received, with responses from 11 reviewers. After three contact attempts, there was no feedback from a female reviewer. The CVR value for the items and the global $\mathrm{CVI}$ were calculated again, according to criteria ${ }^{24}$, and the recommendations were qualitatively assessed. At the end of this phase, the pre-final version (PFV) was obtained.

The main researcher assessed the recommendations of the translations and reviews, to identify potential problems, clarify doubts, and guide the language reviewer as to the target language (Stage 6). One of the reviewers, a language specialist and native of the target culture, participant of Reviewers Committee 1, was invited to assess the adaptation procedure and received the PFV of the instrument (Stage 7).

The main researcher verified all the documentation of the CCA process - with special attention to the problematic items - to avoid discrepancies between the translations and the original version, preserving conceptual equivalence (Stage 8). Subsequently, the PFV of the instrument was reviewed, the material was given format and design, and the grammatical errors were corrected, considering the recommendations made by the reviewers (Stage9). At the end of this stage, the author of the instrument was consulted regarding her approval of the PFV.

The PFV was subjected to a cognitive test (Stage 10), with undergraduate Nursing students as target audience. Eight students, inserted in activities in the research groups to which the main researcher is linked, in each institution, initiated the assessment and indicated other potential participants; and so on, until reaching the number of 31 students. They were invited via email and, after self-completion of the PFV, they were instructed to answer an online form, the items that generated doubts or were not understood being reviewed, until reaching a minimum agreement of $80 \%$ regarding understanding of the items ${ }^{22}$. In order to minimize the limitations inherent to this technique, at the end the students should answer three questions related to (1) understanding, (2) difficulty and (3) constraints when filling out the instrument. The adoption of this technique was due to the need for social distancing in the face of COVID-19.

At the end of the cognitive test, the researchers analyzed the comments (Stage 11) and obtained the consolidated Brazilian version of the CSM+. This version was sent to the author of the instrument for her analysis and approval.

\section{RESULTS}

The CCA process lasted approximately ten months, and strictly followed the methodological stages proposed in the literature. The CSM+ was translated into the Portuguese language spoken in Brazil and was then called Positive Mental Health Questionnaire - Brazilian version (CSM+). The original acronym of the scale was maintained, with the objective of ensuring its recognition by peers in the international scientific community.

The initial translations, performed independently by two translators, achieved close versions; none of the translators reported difficulties in translating the meanings of the items. In view of the 
similarities in both translations, small adjustments were necessary during the second stage. The reconciled version was backtranslated into Spanish, to identify the suitability of the meanings of the items between the translated and the original versions.

Comparative charts were prepared between the original and translated versions, to ensure clarity to the reviewers about the objectives of the items. The author of the instrument was consulted for her to assess whether the translations obtained contemplated the meanings of the items in the original version and, if necessary, suggest adjustments. At the end of this process, the Portuguese translation was obtained to be assessed by Reviewers Committee 1. In this version, punctuation adjustments were made, removing the reticence contained in the original version, as they are not commonly used in Brazil.

This version was submitted to the assessment of translation quality, through the analysis of equivalences, by Reviewers Committee 1. Table 1 presents the agreement index regarding the conceptual, idiomatic, semantic, and experimental equivalences.

Table 1 -Agreement index among the reviewers regarding the idiomatic, experimental, semantic, and conceptual equivalences. Rio de Janeiro, RJ, Brazil, 2019-2020 ( $n=7)$.

\begin{tabular}{ccccc}
\hline Item & Conceptual & Idiomatic & Semantic & Experimental \\
\hline i1 & $07(100 \%)$ & $07(100 \%)$ & $07(100 \%)$ & $07(100 \%)$ \\
i2 & $07(100 \%)$ & $07(100 \%)$ & $07(100 \%)$ & $07(100 \%)$ \\
i3 & $07(100 \%)$ & $07(100 \%)$ & $07(100 \%)$ & $07(100 \%)$ \\
i4 & $07(100 \%)$ & $07(100 \%)$ & $07(100 \%)$ & $07(100 \%)$ \\
i5 & $07(100 \%)$ & $07(100 \%)$ & $07(100 \%)$ & $07(100 \%)$ \\
i6 & $07(100 \%)$ & $07(100 \%)$ & $07(100 \%)$ & $07(100 \%)$ \\
i7 & $07(100 \%)$ & $07(100 \%)$ & $07(100 \%)$ & $07(100 \%)$ \\
i8 & $07(100 \%)$ & $06(85.7 \%)$ & $07(100 \%)$ & $07(100 \%)$ \\
i9 & $07(100 \%)$ & $07(100 \%)$ & $07(100 \%)$ & $07(100 \%)$ \\
i10 & $07(100 \%)$ & $06(85.7 \%)$ & $07(100 \%)$ & $06(85.7 \%)$ \\
i11 & $07(100 \%)$ & $05(71.4 \%)$ & $06(85.7 \%)$ & $07(100 \%)$ \\
i12 & $07(100 \%)$ & $07(100 \%)$ & $07(100 \%)$ & $07(100 \%)$ \\
i13 & $07(100 \%)$ & $07(100 \%)$ & $07(100 \%)$ & $07(100 \%)$ \\
i14 & $07(100 \%)$ & $07(100 \%)$ & $07(100 \%)$ & $06(85.7 \%)$ \\
i15 & $07(100 \%)$ & $07(100 \%)$ & $07(100 \%)$ & $07(100 \%)$ \\
i16 & $07(100 \%)$ & $06(85.7 \%)$ & $07(100 \%)$ & $06(85.7 \%)$ \\
i17 & $07(100 \%)$ & $07(100 \%)$ & $06(85.7 \%)$ & $07(100 \%)$ \\
i18 & $07(100 \%)$ & $06(85.7 \%)$ & $07(100 \%)$ & $05(71.4 \%)$ \\
i19 & $07(100 \%)$ & $06(85.7 \%)$ & $07(100 \%)$ & $06(85.7 \%)$ \\
i20 & $07(100 \%)$ & $06(85.7 \%)$ & $07(100 \%)$ & $07(100 \%)$ \\
i21 & $07(100 \%)$ & $05(71.4 \%)$ & $07(100 \%)$ & $07(100 \%)$ \\
i22 & $07(100 \%)$ & $07(100 \%)$ & $07(100 \%)$ & $07(100 \%)$ \\
i23 & $07(100 \%)$ & $07(100 \%)$ & $07(100 \%)$ & $07(100 \%)$ \\
i24 & $07(100 \%)$ & $07(100 \%)$ & $07(100 \%)$ & $07(100 \%)$ \\
i25 & $07(100 \%)$ & $07(100 \%)$ & $07(100 \%)$ & $07(100 \%)$ \\
i26 & $07(100 \%)$ & $06(85.7 \%)$ & $07(100 \%)$ & $07(100 \%)$ \\
i27 & $07(100 \%)$ & $06(85.7 \%)$ & $07(100 \%)$ & $07(100 \%)$ \\
i28 & $07(100 \%)$ & $04(57.1 \%)$ & $06(85.7 \%)$ & $06(85.7 \%)$ \\
i29 & $07(100 \%)$ & $06(85.7 \%)$ & $07(100 \%)$ & $07(100 \%)$ \\
\hline & & & &
\end{tabular}


Table 1 - Cont.

\begin{tabular}{rcccc}
\hline Item & Conceptual & Idiomatic & Semantic & Experimental \\
\hline i30 & $07(100 \%)$ & $05(71.4 \%)$ & $07(100 \%)$ & $07(100 \%)$ \\
i31 & $07(100 \%)$ & $06(85.7 \%)$ & $07(100 \%)$ & $07(100 \%)$ \\
i32 & $07(100 \%)$ & $06(85.7 \%)$ & $07(100 \%)$ & $07(100 \%)$ \\
i33 & $07(100 \%)$ & $07(100 \%)$ & $07(100 \%)$ & $07(100 \%)$ \\
i34 & $07(100 \%)$ & $05(71.4 \%)$ & $07(100 \%)$ & $06(85.7 \%)$ \\
i35 & $07(100 \%)$ & $07(100 \%)$ & $07(100 \%)$ & $07(100 \%)$ \\
i36 & $07(100 \%)$ & $05(71.4 \%)$ & $07(100 \%)$ & $07(100 \%)$ \\
i37 & $07(100 \%)$ & $07(100 \%)$ & $07(100 \%)$ & $07(100 \%)$ \\
i38 & $07(100 \%)$ & $07(100 \%)$ & $07(100 \%)$ & $07(100 \%)$ \\
i39 & $07(100 \%)$ & $06(85.7 \%)$ & $07(100 \%)$ & $07(100 \%)$ \\
\hline
\end{tabular}

It was verified that 20 items presented recommendations, mostly in the sense of preserving the perceptions contained in the original version of the items; that is, in idiomatic equivalence. Of these, seven items showed lower agreement indexes than established, namely: i11, i18, i21, i28, i30, i34 and i36. Among the aforementioned, exclusively for item i18 the agreement index in the experimental equivalence was not reached; the others referred to idiomatic equivalence. Chart 1 presents the synthesis of these recommendations.

All the changes were validated by a female professional, expert in spelling and grammatical reviews, who assisted in the analysis of the reviewers' comments, to ensure clarity and colloquiality of the items. Although they did not present an agreement index lower than that established, but had recommendations from the reviewers, the other items were analyzed qualitatively, and it was noticed that the suggested changes referred to small adjustments of terms placement in the items. In these cases, it was decided to wait for the next stages, and, if necessary, modify them.

Chart 1 - Synthesis of the recommendations made by Reviewers Committee 1. Rio de Janeiro, RJ, Brazil, 2019-2020.

\begin{tabular}{|c|l|l|}
\hline Item & \multicolumn{1}{|c|}{ Suggestions } & \multicolumn{1}{|c|}{ Decision } \\
\hline i11 & $\begin{array}{l}\text { Penso que tenho muita capacidade de me colocar no lugar dos } \\
\text { outros e compreender suas opiniões (I feel that I have a strong } \\
\text { ability to put myself in the shoes of others and to understand } \\
\text { their responses) (Reviewer 1). } \\
\text { Acredito que tenho muita capacidade para colocar-me no } \\
\text { lugar dos outros e compreender suas reações (I feel that I I } \\
\text { have a strong ability to put myself in the others' shoes and to } \\
\text { understand their responses) (Reviewer 2). }\end{array}$ & $\begin{array}{l}\text { Merging of the suggestions } \\
\text { into: acredito que tenho } \\
\text { muita capacidade de me } \\
\text { colocar no lugar dos outros e } \\
\text { compreender suas reações. }\end{array}$ \\
\hline i18 & $\begin{array}{l}\text { Evaluate the use of the term psicólogo (psychologist), considering } \\
\text { that it can cause estrangement in the target audience. }\end{array}$ & $\begin{array}{l}\text { Wait for the next stages, } \\
\text { and make the adjustments, } \\
\text { if necessary. }\end{array}$ \\
\hline i21, i30, i34 & $\begin{array}{l}\text { Changes related to pronominal placement and position } \\
\text { of terms (adjectives). }\end{array}$ & $\begin{array}{l}\text { Colloquiality and adequacy } \\
\text { were preferred rather than the } \\
\text { cultured norm. }\end{array}$ \\
\hline i28 & Use diante de (in view of) and not perante (because of). & $\begin{array}{l}\text { The committee's } \\
\text { recommendation was chosen. }\end{array}$ \\
\hline i32 & Use potencializar (enhance) and not fortalecer (strengthen). & $\begin{array}{l}\text { The committee's } \\
\text { recommendation was chosen. }\end{array}$ \\
\hline
\end{tabular}


After the adjustments, when consulted about the referrals made by the researchers, the reviewers agreed with the decisions made and emphasized that the process included idiomatic equivalence, as well as the cultured norm of the Portuguese language.

After the reviews, version S2 was attained, which was sent for review by Reviewers Committee 2, responsible for content evaluation. Table 2 shows the CVR value for each type of evidence and the mean CVR, in the two assessment rounds.

Table 2 - Evidence of validity related to the content of the Positive Mental Health Questionnaire - Brazilian version, according to the values of content validity ratio and content validity index. Rio de Janeiro, RJ, Brazil, 2020.

\begin{tabular}{|c|c|c|c|c|c|c|c|c|c|c|}
\hline \multirow{2}{*}{$\begin{array}{c}\text { Item } \\
\text { Round }\end{array}$} & \multicolumn{2}{|c|}{ Clarity } & \multicolumn{2}{|c|}{ Pertinence } & \multicolumn{2}{|c|}{ Relevance } & \multicolumn{2}{|c|}{ Dimensionality } & \multicolumn{2}{|c|}{$\mathrm{CVI}^{*}$} \\
\hline & 1 & 2 & 1 & 2 & 1 & 2 & 1 & 2 & 1 & 2 \\
\hline $\mathrm{i} 1$ & 0.500 & 0.818 & 0.833 & 1 & 1 & 1 & 1 & 1 & 0.833 & 0.954 \\
\hline i2 & 1 & 1 & 0.833 & 1 & 1 & 1 & 1 & 1 & 0.958 & 0.958 \\
\hline i3 & 0.333 & 1 & 0.833 & 1 & 1 & 1 & 1 & 1 & 0.792 & 1 \\
\hline ¡4 & 0.833 & 1 & 0.833 & 1 & 1 & 1 & 1 & 1 & 0.917 & 1 \\
\hline ¡5 & 1 & 1 & 1 & 1 & 1 & 1 & 1 & 1 & 1 & 1 \\
\hline i6 & 0.833 & 1 & 0.833 & 1 & 1 & 1 & 1 & 1 & 0.917 & 1 \\
\hline$i 7$ & 1 & 0.818 & 1 & 0.636 & 1 & 0.636 & 1 & 1 & 1 & 0.772 \\
\hline i8 & 0.333 & 1 & 0.833 & 1 & 1 & 1 & 1 & 1 & 0.792 & 1 \\
\hline i9 & 0.666 & 0.818 & 0.833 & 1 & 1 & 0.818 & 1 & 1 & 0.875 & 0.909 \\
\hline i10 & 1 & 1 & 1 & 1 & 1 & 1 & 1 & 1 & 1 & 1 \\
\hline i11 & 1 & 1 & 0.833 & 0.818 & 1 & 0.818 & 1 & 1 & 0.958 & 0.909 \\
\hline ¡12 & 0.833 & 1 & 0.833 & 1 & 1 & 1 & 1 & 1 & 0.917 & 1 \\
\hline i13 & 1 & 1 & 1 & 1 & 1 & 1 & 1 & 1 & 1 & 1 \\
\hline ¡14 & 1 & 1 & 1 & 1 & 1 & 1 & 1 & 1 & 1 & 1 \\
\hline ¡15 & 1 & 1 & 1 & 1 & 1 & 1 & 1 & 1 & 1 & 1 \\
\hline ¡16 & 0.833 & 1 & 0.833 & 1 & 1 & 1 & 1 & 1 & 0.917 & 1 \\
\hline ¡17 & 1 & 1 & 1 & 1 & 1 & 1 & 1 & 1 & 1 & 1 \\
\hline ¡18 & 0.333 & 1 & 0.666 & 1 & 0.500 & 1 & 0.833 & 1 & 0.583 & 1 \\
\hline ¡19 & 0.833 & 1 & 0.833 & 1 & 1 & 1 & 1 & 1 & 0.917 & 1 \\
\hline i20 & 0.833 & 1 & 1 & 1 & 1 & 1 & 1 & 1 & 0.958 & 1 \\
\hline i21 & 1 & 1 & 1 & 1 & 1 & 1 & 1 & 1 & 1 & 1 \\
\hline ¡22 & 1 & 1 & 1 & 1 & 1 & 1 & 1 & 1 & 1 & 1 \\
\hline i23 & 1 & 1 & 1 & 1 & 1 & 1 & 1 & 1 & 1 & 1 \\
\hline i24 & 0.500 & 0.818 & 0.833 & 1 & 1 & 1 & 1 & 1 & 0.833 & 0.954 \\
\hline i25 & 1 & 1 & 1 & 1 & 0.666 & 1 & 1 & 1 & 0.917 & 1 \\
\hline i26 & 1 & 1 & 1 & 1 & 1 & 1 & 1 & 1 & 1 & 1 \\
\hline i27 & 0.833 & 1 & 1 & 1 & 1 & 1 & 1 & 1 & 0.958 & 1 \\
\hline i28 & 0.833 & 1 & 0.833 & 1 & 0.833 & 1 & 1 & 1 & 0.875 & 1 \\
\hline i29 & 0.833 & 1 & 0.833 & 1 & 1 & 1 & 1 & 1 & 0.917 & 1 \\
\hline i30 & 0.833 & 1 & 0.833 & 1 & 0.833 & 1 & 0.833 & 1 & 0.833 & 1 \\
\hline i31 & 1 & 1 & 0.833 & 0.454 & 1 & 0.454 & 0.833 & 1 & 0.917 & 0.727 \\
\hline i32 & 1 & 0.818 & 0.833 & 0.818 & 1 & 0.818 & 0.833 & 0.818 & 0.917 & 0.818 \\
\hline i33 & 0.833 & 1 & 0.833 & 1 & 0.833 & 0.818 & 0.833 & 1 & 0.833 & 0.954 \\
\hline ¡34 & 1 & 1 & 1 & 1 & 1 & 1 & 0.833 & 1 & 0.958 & 1 \\
\hline ¡35 & 0.833 & 1 & 0.833 & 1 & 1 & 1 & 1 & 1 & 0.917 & 1 \\
\hline
\end{tabular}


Table 2 - Cont.

\begin{tabular}{ccccccccccc}
\hline Item & \multicolumn{2}{c}{ Clarity } & \multicolumn{2}{c}{ Pertinence } & \multicolumn{2}{c}{ Relevance } & \multicolumn{2}{c}{ Dimensionality } & \multicolumn{2}{c}{$\mathbf{C V I}^{*}$} \\
\hline Round & $\mathbf{1}$ & $\mathbf{2}$ & $\mathbf{1}$ & $\mathbf{2}$ & $\mathbf{1}$ & $\mathbf{2}$ & $\mathbf{1}$ & $\mathbf{2}$ & $\mathbf{1}$ & $\mathbf{2}$ \\
\hline i36 & 1 & 1 & 1 & 1 & 1 & 1 & 0.833 & 1 & 0.958 & 1 \\
i37 & 1 & 1 & 0.833 & 1 & 0.833 & 1 & 1 & 1 & 0.917 & 1 \\
i38 & 1 & 1 & 1 & 1 & 1 & 1 & 1 & 1 & 1 & 1 \\
i39 & 0.833 & 1 & 0.833 & 1 & 1 & 1 & 1 & 1 & 0.917 & 1 \\
\hline CVI* & 0.872 & 0.976 & 0.901 & 0.967 & 0.923 & 0.958 & 0.970 & 0.995 & 0.918 & 0.950 \\
\hline
\end{tabular}

${ }^{*} \mathrm{CVI}$ : Content Validity Index.

Only item i18 obtained a mean value lower than the critical CVR. Some reviewers recommended changing the term psicólogo (psychologist) to conselheiro (counselor), understanding that the item's real intention is related to being a good listener or advisor, such as a psychologist. Other reviewers pointed out that the instrument is being adapted for undergraduate Nursing students and health students, in general, know that psychologists do not give advice and, even with the use of quotation marks as a device, the item would be confusing. It was decided to consult the author of the instrument on this item. She described that the intention referred to the person's ability to understand others and then help them. The main researchers then chose to change the item to: Sou capaz de entender os outros e ajudá-los (I consider myself to be a good psychologist).

It is noted that the total of 26 items received at least one recommendation from the reviewers although with a mean CVR higher than the critical limit, which were analyzed qualitatively.

Initially, the instrument's title was questioned regarding clarity. The psychologist asserted that the use of the term positiva (positive) could be interpreted as redundant. However, it was decided to maintain it, as it is the name of the construct assessed.

Regarding the answer options, one of the nurses, with experience in psychometrics, argued that the options sempre ou quase sempre (always or almost always) and nunca ou quase nunca (never or almost never) deserved to appear in separate fields, as they reflected different alternatives. The question was considered by the main researchers, but it was decided to keep them according to the original structure of the instrument, maintaining equivalence between the measurement scales.

Regarding items i1, i3, i8 and i24, the Committee suggested deleting the adverb especialmente (especially), for understanding that it would not affect the clarity of the item. However, the main researchers chose to consult the author of the instrument about the intention in using the term. According to her, the adverb especialmente (especially) appears in items where there is a little difficulty, for example: É muito comum que tenhamos um pouco de dificuldade em aceitar os outros quando eles têm atitudes diferentes das nossas (I find it especially difficult to accept others when their attitudes are different from mine); therefore, it is especially difficult to rate. Therefore, considering that we are assessing frequency, not intensity, in the questionnaire, the term was maintained.

In item i3, the following change was also recommended: Para mim, é especialmente difícil ouvir as pessoas me contarem seus problemas (I find it particularly difficult to listen to people telling me their problems), justifying clarification of the item. Such a recommendation was accepted.

Four items (i7, i11, i31 and i32) received alerts. Two reviewers pointed out that these items presented double commands and unique answer options; that is, a single item assessed two skills. In these cases, it was decided to keep them according to the original structure, without detriment to the meaning to be captured. Duplicity of the commands, in the original version, is used as a resource to highlight what was previously asked, reinforcing what should be understood by the target audience, and because the second command is considered because of the first. 
In relation to item i9, a reviewer suggested removing the adjective profunda (deep), since in the original version there is only the word satisfactoria (satisfying). According to the main researchers, the deletion would not affect the clarity and pertinence of the item, since having satisfactory relationships is different from having deep relationships; that is, I can have satisfying, but not deep, relationships. The item was thus modified to: Tenho dificuldades para estabelecer relações interpessoais satisfatórias com algumas pessoas (I find it hard to establish deep and satisfying interpersonal relationships with some people).

Items i16, i19, i27 and i29 were modified, respectively, to: Procuro compreender, de forma positiva, as coisas ruins que acontecem comigo (I try to look for the positive side when bad things happen to me); Preocupo-me com as críticas vindas dos outros (It troubles me when people criticize me); Quando surgem mudanças na minha vida, tento me adaptar (When there are changes in my surroundings I try to adapt to them); and As mudanças que ocorrem na minha rotina habitual me estimulam (I find changes in my daily routine to be stimulating). The aforementioned modifications were intended to ensure a better understanding by the respondents, as recommended by the reviewers.

As for item i28, a nurse with experience in CCA and mental health warned that pedir informações (ask for information) might not contemplate the real intention that would be to ask for help/assistance in the face of a problem/situation. It was decided to accept the suggestion, and changed to: Diante de um problema, sou capaz de pedir ajuda (In the face of a problem I am able to ask for information).

Item i33 was questioned as to the clarity about what would be asked. According to one female reviewer, we all have personal opinions, although there may be difficulties in expressing them. So, the meaning of the item was sought in the questionnaire in Spanish, and it was verified that it was an item aimed at capturing the dimension of autonomy, related to the difficulty in elaborating personal opinions. The item was thus modified: Para mim, é difícil desenvolver opiniões próprias (I find it hard to hold my own opinions).

At the end, it was possible to identify those 12 items did not present recommendations and that another 10 items presented suggestions; however, the researchers chose to no modify them, given that the items had already undergone changes at another time. Thus, it was decided to match the original version of the instrument as much as possible, without detriment to the clarity of the items. At the end of this phase, version S3 was obtained.

This version - the result of the content validity assessment by Reviewers Committee 2, in the first round - was submitted to a new evaluation. In this second assessment round of content validity evidence, although the mean CVR of all the items is higher than the critical value, the recommendations obtained were analyzed qualitatively. Only one change was made aiming at greater clarity. One reviewer suggested reversing the sentence structure of item i28 to: Sou capaz de pedir ajuda diante de um problema. After reviewing the comments, the pre-final version (PFV) - with 39 items and a dimensional structure similar to the original version - was sent to the author of the instrument, who consented and approved the new version.

The cognitive test was conducted with 31 students. Most of them were female $(83.9 \%, n=26)$, belonged to the black race $(35.5 \%, n=11)$, single $(83.9 \%, n=26)$, professed Protestantism $(32.3 \%$, $\mathrm{n}=10)$, used public transportation for commuting $(90.3 \%, \mathrm{n}=28)$ and did not practice any physical activity $(51.6 \%, \mathrm{n}=16)$. There were participants from all academic semesters; however, for $17(54.8 \%)$, Nursing was not their first option, and $18(58.1 \%)$ had already thought about giving up the Course. Their mean age was 22.8 years old $(S D=2.3)$, with a minimum of 18 and a maximum of 28 .

The individual analysis of the items, and of the PFV, obtained an acceptable assessment about understanding by the respondents; therefore, they were not modified. In this context, the agreement percentage found varied between $93.5 \%$ and $100 \%$ The qualitative analysis of the comments to the questions of the form revealed that some items related to personal satisfaction, pro-social attitude 
and interpersonal skills can cause constraints to the respondents. The students endorsed the use of the instrument as a good self-reflection measure. This version was approved by the author of the instrument and is configured in the consolidated Brazilian version of the CSM+.

\section{DISCUSSION}

A number of studies have shown that there are several guidelines for the CCA of measurement instruments, but that there is still no consensus on which is the best ${ }^{25-27}$. The CCA process of the $\mathrm{CSM}+$ strictly followed the stages proposed by the chosen method ${ }^{20}$, which has been used in other studies $^{28-29}$. Methodological rigor with attention to the particularities of each stage proved to be essential to guarantee quality and avoid problems at subsequent moments.

The initial translations showed close results and the translators did not identify difficulties, since the questionnaire measures common situations that favor cultural approximation - $a$ fact that is also observed in the CCA process for the Portuguese population ${ }^{9}$. The recommendations made in the reconciliation stage aimed at ensuring more colloquial language, which is preferable in self-applied instruments. It is worth mentioning that the profile of the translators - Brazilians with knowledge of the Spanish culture and language - contributed to minimizing semantic deviations. The fact that the translators worked independently ensured that interpretative mistakes and particularities of the writing were avoided.

The reconciled version was translated into the source language by a Spanish native, with knowledge of the Brazilian culture, and who did not have access to the original version. Subsequently, it was subjected to quality assessment by the author of the instrument. This stage has no consensus among the various CCA guidelines, as well as the number of versions to be obtained; however, a study evidenced that its execution has an impact on the psychometric properties ${ }^{30}$. This stage was considered essential, as it guaranteed equivalence of meanings and served as a communication mechanism with the author of the instrument ${ }^{20,25}$.

The independent review stage took place in two phases: equivalence assessment and content validation. To this end, two groups of reviewers were adopted. The first group - whose members were all bilingual - was responsible for consolidating the Brazilian version of the instrument, which is culturally adequate. In this phase, the participation of two female professionals with Linguistic certifications was essential and ensured semantic harmonization across the versions. In the second phase, most of the reviewers were not bilingual; however, they had expertise in the method or phenomenon, being responsible for a more qualitative assessment of the content of the items, in terms of clarity, relevance, pertinence and dimensionality.

The need for two committees was due to the experience of the group of researchers in this study when realizing that problems in the quality of the translation impact on the assessment of the scale content. Thus, assessing intercultural equivalence before content was shown to be adequate to mitigate issues that can be resolved even in the initial translation stages.

The difficulty in identifying researchers with expertise in PMH in Brazil is highlighted. However, in this study, as well as in CCA for use in Portugal $^{9}$, the profile of the reviewers met the recommendations set forth in the literature ${ }^{20-21}$.

The initial version showed high levels of agreement among the judges regarding intercultural equivalence. The problems identified in six items referred to the use of terms and expressions that would be better understood if stated differently - idiomatic equivalence - and to an item in which the situation evoked was not suitable for the Brazilian population - experimental equivalence. In relation to the content of the items, only item 18 - the same that presented problems in terms of experimental equivalence - obtained CVR values lower than the critical ${ }^{24}$, a fact that required discussions with the author of the instrument. 
More than one assessment rounds by the reviewers' committees were needed to solve the obstacles and avoid cultural bias, which culminated in items written differently from the Portuguese version ${ }^{9}$. This data demonstrates the importance of avoiding the adoption of instruments adapted to other realities without an adequate CCA process, even in the same language. When an instrument is developed in a country with the same language as the target, the literature recommends that the initial translation stages be deleted ${ }^{21}$. However, the instrument under study was developed in a Spanishspeaking country; therefore, the entire CCA process is necessary.

Although the valuesof agreement index and/or CVR are not lower than the predetermined, the recommendations made by the reviewers' committees, for the most part, were considered relevant and allowed cultural adaptation of the items to the Brazilian reality. Another highlight refers to the assembling of these committees with the participation of reviewers from almost all geographic regions of the country - except the Midwest region - since, for Brazil being a country of continental dimensions, diversity in terms of beliefs, behaviors and regionalisms is necessary.

The profile of the participants in the cognitive test met the recommendations set forth in the literature regarding number: 30 to 40 respondents ${ }^{21}$. The items proved to be understandable by the target audience and there was no need for modifications. From the perspective of the target audience, the instrument can be important for examining self-reflection. The performance of the cognitive test, however, reinforced the guidance that the instrument should be self-applied, as some items were identified as constraining by the participants.

Some peculiarities of the CCA process followed in this study must be mentioned because they were facilitators. Firstly, the participation of the instrument's author in the entire process allowed for clarity of the theoretical structure underlying the instrument, providing better organization and safety in decision-making by the researchers. Then, the participation of a female professional qualified to carry out spelling and grammatical reviews of the Portuguese language during the analysis of the initial translations, assisting in the decisions regarding the structure of the items for greater colloquiality. And, finally, the figure of the reconciler - Translator of Stage 2 - who helped in the formatting, harmonization, and review of the final version of the instrument, transcending the literalness of the words.

As a limitation, this study presents the performance of the cognitive test through email, a fact that may have suppressed the considerations in terms of the subjectivity inherent to the items and spontaneity of the answers. Despite the limitation, the results herein presented confirm that selfapplication is the best way to administer the instrument, confirming its use through electronic forms.

Despite the instrument's CCA process was completed, and concluding that there is equivalence across the versions, it is reiterated that it can only be used after the other psychometric evidence have been assessed, a process in progress.

\section{CONCLUSION}

The objective of this study was achieved and, at the end of a rigorous cross-cultural adaptation process, the Positive Mental Health Questionnaire - Brazilian version was obtained. This version present intercultural equivalence in relation to the original version, its content being clear, relevant, and pertinent to the Brazilian context, confirming its easy understanding by the target audience.

An instrument was obtained that, when completed, its psychometric evidence assessment process will be useful for establishing positive mental health levels in the population groups. Such a questionnaire will support self-reflection and the planning of mental health promotion programs. In addition, it may also be used in future research studies to adapt it to other specific audiences, as well as to compare and aggregate data internationally. 


\section{REFERENCES}

1. World Health Organization. Promoting mental health: concepts, emerging evidence and practice. A Report of the World Health Organization, Department of Mental Health and Substance Abuse in collaboration with the Victorian Health Promotion Foundation and The University of Melbourne [Internet]. Geneva (CH): WHO; 2004. [cited 2020 Jul 15]. Available from: https://apps.who.int/ iris/handle/10665/42940

2. Jahoda M. Current concepts of positive mental health. New York, NY(US): Basic Books; 1958.

3. Roldán-Merino J, Lluch-Canut MT, Casas I, Sanromà-Ortíz M, Ferré-Grau C, Sequeira C, et al. Reliability and validity of the Positive Mental Health Questionnaire in a sample of Spanish university students. J Psychiatr Ment Health Nurs [Internet]. 2017 [cited 2019 Feb 24];24:123-33. Available from: https://doi.org/10.1111/.jpm.12358

4. Lluch-Canut MT. Construcción de una escala para evaluar la salud mental positiva [thesis]. Barcelona. Universidade de Barcelona; 1999 [cited 2019 Feb 28]. Available from: https://www. tdx.cat/handle/10803/2366; jsessionid=676ADA2B2FC0C1DA1D9AE31FBCBC1EBD\#page=1

5. Ferreira M, Cortez E, Silva J, Ferreira MJ. Avaliação da saúde mental positiva de discentes de enfermagem. Rev Port Enferm Saúde Ment [Internet]. 2016 [cited 2019 Feb 25];Spe 4:57-62. Available from: https://doi.org/10.19131/rpesm.0142

6. Angulo LGR. Impacto de un programa de promoción del autocontrol en estudiantes de enfermería. Enferm Clin [Internet]. 2018 [cited 2020 Apr 20];28(2):118-24. Available from: https://doi. org/10.1016/j.enfcli.2017.03.012

7. Sequeira C, Carvalho JC, Gonçalves A, Nogueira MJ, Lluch-Canut T, Roldán-Merino J. Levels of positive mental health in Portuguese and Spanish nursing students. J Am Psychiatr Nurses Assoc [Internet]. 2019 [cited 2020 Apr 20];26(5):483-92. Available from: https://doi. org/10.1177/1078390319851569

8. Sequeira C, Carvalho JC, Sampaio F, Sá L, Lluch-Canut T, Roldán-Merino J. Avaliação das propriedades psicométricas do Questionário de Saúde Mental Positiva em estudantes portugueses do ensino superior. Rev Port Enferm Saude Ment [Internet]. 2014 [cited 2020 Jul 31]; 11:45-53. Available from: http://www.scielo.mec.pt/scielo.php?script=sci_arttext\&pid=S1647-21602014000200007

9. Carvalho JC, Sequeira C. Tradução para a população portuguesa do Questionário de Saúde Mental Positiva (QSM+). In: Sequeira C, Carvalho JC, Ribeiro I, Martins T, Rodrigues T, eds. Qualidade de vida em análise. Porto (PT): Escola Superior de Enfermagem do Porto; 2009. p. 303-14

10. Hurtado-Pardos B, Lluch-Canut T, Casas-García I, Sequeira C, Puig-Llobet M, Roldán-Merino J. Evaluación de la fiabilidad y validez del Cuestionario de Salud Mental Positiva en profesores universitarios de enfermería en Cataluña. Rev Enferm Salud Ment [Internet]. 2018 [cited 2019 Feb 28];9:5-17. Available from: https://doi.org/10.5538/2385-703X.2018.9.5

11. Anicana J, Caballero G, Cirilo I, Aguirre M, Briceño R, Tomás A. Autoeficacia y salud mental positiva en estudiantes de Psicología de Lima. Rev Psicol Trujillo (Perú) [Internet]. 2012 [cited 2020 Jul 31];14(2):144-63. Available from: https://sisbib.unmsm.edu.pe/BVRevistas/rev_psicologia_cv/ v14_2012_2/pdf/a02v14n2.pdf

12. Hurtado-Pardos $B$, Moreno-Arroyo $C$, Casas I, Lluch-Canut T, Lleixà-Fortuño M, Farrés-Tarafa $\mathrm{M}$, et al. Positive mental health and prevalence of psychological ill-being in university nursing professors in Catalonia, Spain. J Psychosoc Nurs Ment Health Serv [Internet]. 2017 [cited 2019 Feb 28];55(7):38-48. Available from: https://doi.org/10.3928/02793695-20170619-06

13. Mantas-Jiménez $S$, Juvinyà-Canal $D$, Bertran-Noguer $C$, Roldán-Merino J, Sequeira $C$, Lluch-Canut MT. Evaluation of positive mental health and sense of coherence in mental health professionals. Rev Port Enferm Saude Ment [Internet]. 2015 [cited 2020 Jul 31];13:34-42. Available from: http:// www.scielo.mec.pt/scielo.php?script=sci_arttext\&pid=S1647-21602015000200005\&lng=pt 
14. Lluch-Canut T, Puig-Llobet M, Sánchez-Ortega A, Roldán-Merino J, Ferré-Grau C, Positive Mental Health Research Group. Assessing positive mental health in people with chronic physical health problems: correlations with socio-demographic variables and physical health status. BMC Public Health [Internet]. 2013 [cited 2019 Feb 28];13:928. Available from: https://doi.org/10.1186/14712458-13-928

15. Ballester L, Alayo I, Vilagut G, Almenara J, Cebrià Al, Echeburúa E, et al. Accuracy of online survey assessment of mental disorders and suicid althoughts and behaviors in Spanish university students. Results of the WHO World Mental Health-International College Student initiative. PloS ONE [Internet]. 2019 [cited 2020 Apr 20];14(9):e0221529. Available from: https://doi.org/10.1371/ journal.pone.0221529

16. Bresolin JZ, Dalmolin GL, Vasconcellos SJL, Barlem ELD, Andolhe R, Magnago TSBS. Depressive symptoms among healthcare undergraduate students. Rev Latino-Am Enfermagem [Internet]. 2020 [cited 2020 Mar 17];28:e3239. Available from: https://doi.org/10.1590/1518-8345.3210.3239

17. Wang $\mathrm{AH}$, Lee $\mathrm{CT}$, Espin S. Undergraduate nursing students' experiences of anxiety-producing situations in clinical practicums: a descriptive survey study. Nurse Educ Today [Internet]. 2019 [cited 2020 Apr 20];76:103-8. Available from: https://doi.org/10.1016/j.nedt.2019.01.016

18. Silva RM, Costa ALS, Mussi FC, Lopes VC, Batista KM, Santos OP. Health alterations in nursing students after a year from admission to the undergraduate course. Rev Esc Enferm USP [Internet]. 2019 [cited 2020 Apr 08];53:e03450. Available from: https://doi.org/10.1590/ S1980-220X2018008103450

19. Brailovskaiaa J, Forkmannb T, Glaesmerc H, Paashausa L, Rathb D, Schönfelderc A, et al. Positive mental health moderates the association between suicide ideation and suicide attempts. J. Affect. Disord [Internet]. 2019 [cited 2020 Apr 08];245:246-9. Available from: https://doi.org/10.1016/j. jad.2018.11.005

20. Patient-Reported Outcomes Measurement Information System (PROMIS ${ }^{\circledR}$ ). Instrument Development and Validation Scientific Standards Version 2.0 [Internet]. 2013 [cited 2020 May 11]. Available from: http://www.healthmeasures.net/images/promis/promisstandards_vers2.0_final.pdf

21. Beaton DE, Bombardier C, Guillemin F, Ferraz MB. Guidelines for the process of cross-cultural adaptation of selfreport measures. Spine [Internet]. 2000 [cited 2019 Feb 28];16(2):3186-91. Available from: https://doi.org/10.1097/00007632-200012150-00014

22. Rubio DM, Berg-Weger M, Tebb SS, Lee S, Rauch S. Objectifying content validity: conducting a content validity study in social work research. Soc Work Res [Internet]. 2003 [cited 2019 Feb 28];27(2):94-105. Available from: http://www.jstor.org/stable/42659521

23. Ohrbrach R, Bjorner J, Jezewski M, John MT, Lobbezoo F. Guidelines for establishing cultural equivalence of struments [Internet]. Buffalo, NY(US): Committee for Translations and Protocols International RDC/TMD Consortium Network; 2013 [cited 2020 Jul 31]. Available from: https:// ubwp.buffalo.edu/rdc-tmdinternational/wp-content/uploads/sites/58/2017/01/guidelines-fortranslation-and-cultural-equivalency-of-instruments-2013_05_118608.pdf

24. Ayre C, Scally AJ. Critical values for Lawshe's content validity ratio: revisiting the original methods of calculation. Meas Eval Couns Dev [Internet]. 2014 [cited 2019 Feb 28];47(1):79-86. Available from: https://doi.org/10.1177/0748175613513808

25. Machado RS, Fernandes ADBF, Oliveira ALCB, Soares LS, Gouveia MTO, Silva GRF. Cross-cultural adaptation methods of instruments in the nursing area. Rev Gaucha Enferm [Internet]. 2018 [cited 2019 Feb 25];39:e2017-0164. Available from: https://doi.org/10.1590/1983-1447.2018.2017-0164

26. Oliveira F, Kuznier TP, Souza CC, Chianca TCM. Theoretical and methodological aspects for the cultural adaptation and validation of instruments in nursing. Texto Contexto Enferm [Internet]. 2018 [cited 2019 Feb 25];27(2):e4900016. Available from: https://doi.org/10.1590/0104070720180004900016 
27. Epstein J, Santo RM, Guillemin F. A review of guidelines for cross-cultural adaptation of questionnaires could not bring out a consensos. J Clin Epidemiol [Internet]. 2015 [cited 2019 Feb 25];68:435-41. Available from: https://doi.org/10.1016/j.jclinepi.2014.11.021

28. Silva MCL, Mendonça TMS, Silva CHM, Pinto RMC. Cross-cultural adaptation to Portuguese of a measure of satisfaction with participation of the Patient-Reported Outcomes Measurement Information System (PROMIS ${ }^{\circledR}$ ). Trends Psychiatry Psychother [Internet]. 2015 [cited 2019 Feb 25];37(2):94-9. Available from: https://doi.org/10.1590/2237-6089-2014-0035

29. Zumpano CE, Mendonça TMS, Silva CHM, Correia H, Arnold B, Pinto RMC. Cross-cultural adaptation and validation of the PROMIS ${ }^{\circledR}$ Global Health scale in the Portuguese language. Cad Saude Publica [Internet]. 2017 [cited 2019 Feb 25];33(1):e00107616. Available from: https://doi. org/10.1590/0102-311X00107616

30. Epstein J, Osborne RH, Elsworth GR, Beaton DE, Guillemin F. Cross-cultural adaptation of the Health Education Impact Questionnaire: experimental study showed expert committee, not backtranslation, added value. J Clinical Epidemiol [Internet]. 2015 [cited 2019 Feb 25];68(4):360-9. Available from: https://doi.org/10.1016/j.jclinepi.2013.07.013 


\section{NOTES}

\section{ORIGIN OF THE ARTICLE}

Extracted from the thesis - Cross-cultural adaptation and psychometric evidence of the Cuestionario de Salud Mental Positiva for undergraduate Nursing students in the Brazilian context, to be presented at the Graduate Program in Nursing, Escola de Enfermagem Anna Nery, Universidade Federal do Rio de Janeiro, in progress.

\section{CONTRIBUTION OF AUTHORITY}

Study design: Sousa KHJF, Zeitoune RCG.

Data collection: Sousa KHJF.

Data analysis and interpretation: Sousa KHJF, Lluch-Canut MT, Gallasch CH, Zeitoune RGC.

Discussion of the results: Sousa KHJF, Lluch-Canut MT, Gallasch CH, Zeitoune RGC.

Writing of the content: Sousa KHJF.

Critical review of the content: Lluch-Canut MT, Gallasch CH, Zeitoune RGC.

Review and final approval of the final version: Sousa KHJF, Lluch-Canut MT, Gallasch CH, Zeitoune RGC.

\section{ACKNOWLEDGMENT}

To the Commission for the Improvement of Higher Education Personnel (CAPES) for granting a Doctoral Scholarship to Kayo Henrique Jardel Feitosa Sousa. Process number 88887.333968/2019-00.

\section{APPROVAL OF ETHICS COMMITTEE IN RESEARCH}

Approved by the Research Ethics Committee of the São Instituto de Atenção à Saúde São Francisco de Assis / Escola de Enfermagem Anna Nery, opinion No.3,596,999/2019, Certificate of Presentation for Ethical Appreciation (CAAE) 20382919.6.0000.5238, and amendments No.3,924,797/2020 and 4,069,084/2020; and in the Research Ethics Committee of Universidade Federal do Rio de Janeiro, opinion No.3,636,294/2019, CAAE 20382919.6.3001.5282 and amendments No.3,981,517/2020 and No.4,092,615/2020.

\section{CONFLICT OF INTEREST}

There is no conflict of interests.

\section{EDITORS}

Associated Editors: Selma Regina de Andrade, Gisele Cristina Manfrini, Natália Gonçalves, Ana Izabel Jatobá de Souza.

Editor-in-chief: Roberta Costa.

\section{HISTORICAL}

Received: September 24, 2020.

Approved: February 04, 2021.

\section{CORRESPONDING AUTHOR}

Kayo Henrique Jardel Feitosa Sousa

kayohenriquejardel@gmail.com

\section{SUPPLEMENTARY MATERIAL}

The following online material is available for this article:

Annex 